\title{
Implementasi Augmented Reality Pada Aplikasi Hope Berbasis Android
}

\author{
Suroso $^{* 1}$, Nasron ${ }^{2}$, Ihzany Vilia Devi ${ }^{3}$ \\ ${ }^{1,2} \mathrm{Jl}$. Srijaya Negara, Bukit Besar, Kec. Ilir Bar. I, \\ Kota Palembang, Sumatera Selatan, (0711)353414 \\ ${ }^{3}$ Jurusan Teknik Elektro Program Studi Teknik Telekomunikasi, POLSRI, Palembang \\ e-mail: *11 osurus11@gmail.com, ${ }^{2}$ nasronrahman19@ gmail.com, ${ }^{3}$ ihzanyviliadevi@gmail.com
}

\begin{abstract}
Abstrak
Dalam mempelajari telekomunikasi mahasiswa diwajibkan untuk menguasai alat telekomunikasi yang sering digunakan di laboratorium. Mahalnya alat telekomunikasi menyebabkan mahasiswa harus bergantian dalam mengamati dan mempelajari alat telekomunikasi tersebut. Apabila mahasiswa tidak berhati-hati dalam menggunakan peralatan telekomunikasi milik laboratorium maka kemungkinan peralatan akan cepat rusak sehingga menyebabkan proses belajar mengajar menjadi terganggu. Maka di perlukan aplikasi interaktif yang dapat memberikan pembelajaran baik secara visual maupun auditorial berbasis android yang dapat diakses kapan saja dan dimana saja. Dari hasil evaluasi penilaian yang dilakukan terhadap aplikasi HOPE mendapatkan skor 84,46 yang berarti aplikasi HOPE dinyatakan acceptable termasuk dalam grade A dan B dengan rating excellent, Sehingga aplikasi HOPE dapat meningkatkan nilai peringkat Indonesia pada aspek kemampuan menerima pembelajaran siswa.
\end{abstract}

Kata kunci-Augmented Reality, 3D Object, Android, Unity, Marker Based Tracking

\begin{abstract}
In studying telecommunications, students are required to master telecommunications equipment which is often used in laboratories. The high cost of telecommunication tools causes students to take turns observing and studying these telecommunication tools. If students are not careful in using the laboratory's telecommunication equipment, it is possible that the equipment will break down quickly, causing the teaching and learning process to be disrupted. So an interactive application is needed that can provide learning both visually and audibly based on Android that can be accessed anytime and anywhere. From the results of the evaluation of the assessment carried out on the HOPE application, it gets a score of 84.46, which means that the HOPE application is acceptable, including in grade $A$ and $B$ with an excellent rating, so that the HOPE application can increase Indonesia's rating in the aspect of the ability to accept student learning.
\end{abstract}

Keywords - Augmented Reality, 3D Object, Android, Unity, Marker Based Tracking

\section{PENDAHULUAN}

Tenurut hasil survei yang dirilis oleh Programme for International Student Assessment (PISA) di Paris pada tahun 2015, menempatkan Indonesia di peringkat ke-65 dari 69 negara dalam hal kemampuan menerima pembelajaran [1]. Pada era pendidikan 4.0 pengajar dituntut menjadi pendamping, penyemangat dan fasilitator sehingga mahasiswa menjadi lebih aktif. Dalam mempelajari telekomunikasi mahasiswa diwajibkan untuk menguasai alat 
telekomunikasi yang sering digunakan di laboratorium. Mahalnya alat telekomunikasi menyebabkan mahasiswa harus bergantian dalam mengamati dan mempelajari alat telekomunikasi tersebut. Apabila mahasiswa tidak berhati-hati dalam menggunakan peralatan telekomunikasi milik laboratorium maka kemungkinan peralatan akan cepat rusak sehingga menyebabkan proses belajar mengajar menjadi terganggu.

Proses pembelajaran diarahkan kepada kemampuan mahasiswa untuk menghafal informasi, otak mahasiswa dipaksa untuk mengingat dan menimbun berbagai informasi yang di dapat dari pendidik. Gaya belajar visual adalah suatu bentuk gaya belajar dengan cara melihat, mengamati, dan memandang suatu obyek yang dipelajari sedangkan gaya belajar auditorial adalah gaya belajar dengan cara mendengar. Belajar dengan gaya visual dan gaya auditorial memberikan konstribusi positif terhadap hasil belajar mahasiswa dengan komposisi 46,9\% untuk gaya belajar visual dan 43,6\% untuk gaya belajar auditorial [2].

Augmented reality (AR) merupakan teknologi yang memvisualisasikan benda maya dua dimensi atau tiga dimensi ke dalam sebuah lingkungan nyata tiga dimensi lalu memproyeksikan benda-benda maya tersebut dalam waktu nyata [3]. Mekanisme implementasi Augmented reality dimulai dengan pembuatan object $3 D$ menggunakan SketchUp, pembuatan audio dengan voice recorder, pembuatan $Q R$ Code menggunakan $Q R$ Code generator. Kemudian $Q R$ Code, Object $3 D$ dan audio akan di bentuk menjadi aplikasi augmented reality berbasis android pada Unity. Setelah dilakukan coding di Unity maka selanjutnya akan dilakukan proses compfile, hasil proses compfile tersebut akan menghasilkan file format berkas yang dapat di install pada sistem operasi android berbentuk file APK. Cara kerjanya dengan menggunakan kamera sebagai perangkat pada aplikasi HOPE, Kamera EasyAR akan mendeteksi $Q R$ Code sebagai penanda dan QR Code akan memproyeksikan object $3 D$ dan audio.

Aplikasi tersebut direncanakan menerapkan metode Marked Based Tracker. Metode tersebut menggunakan ilustrasi berbentuk persegi panjang, berwarna hitam dan putih serta terdapat batasan hitam tebal berlatar belakang putih. Lebih lanjut, metode marker based tracking menggunakan ruang tiga dimensi dengan sumbu utama $\mathrm{X}, \mathrm{Y}$, dan $\mathrm{Z}$ dengan bantuan titik koordinat awal $(0,0,0)$ dan juga virtual secara 3 dimensi. Objek tiga dimensi akan diberi tanda dengan tiga sumbu utama yaitu $\mathrm{X}, \mathrm{Y}$, dan $\mathrm{Z}$ untuk memunculkan objek maya [4]. Nantinya aplikasi HOPE ini akan diujikan menggunakan pengujian marker, blackbox testing dan usability untuk mengetahui sejauh mana produk dapat digunakan oleh pengguna tertentu untuk mencapai tujuan yang ditentukan dengan efektifitas, efisiensi, dan kepuasan dalam konteks yang ditentukan untuk digunakan [5]. Pada akhirnya, aplikasi tersebut akan diberi nama HOPE yang bermakna "harapan" dan direncanakan akan di instal pada handphone android. Sesuai dengan maknanya, aplikasi HOPE diharapkan dapat meningkatkan nilai peringkat Indonesia pada aspek kemampuan menerima pembelajaran siswa.

\section{METODE PENELITIAN}

Mekanisme penerapan dan pemanfaatan teknologi Augmented Reality sebagai teknologi utama pada aplikasi HOPE dilakukan dengan terlebih dahulu menyiapkan langkah-langkah pelaksanaan yang sistematis sesuai dengan logika dan fungsi masing-masing unsur atau elemen pendukung dari sistem operasional prototype aplikasi HOPE. Berikut pada gambar 1 menunjukkan skema urutan pelaksanaan pembuatan aplikasi tersebut. 


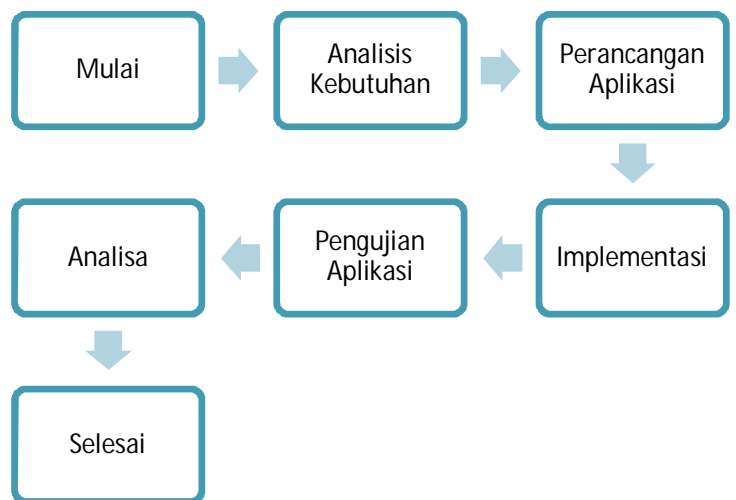

Gambar 1. Kerangka Penelitian

Penelitian ini dilaksanakan dalam 5 tahap. Tahap pertama adalah studi literatur dan persiapan data yang bertujuan untuk mempelajari dasar teori dari literatur mengenai Augmented Reality, Unity, EasyAR, SketchUp dan Photoshop CC. Tahap kedua membuat perancangan aplikasi, yaitu melakukan perincian mengenai apa saja yang dibutuhkan dalam pembuatan aplikasi seperti persiapan objek 3D di SketchUp, QR Code dan Audio. Tahap ketiga Implementasi dimana pada tahap ini konsep perancangan dibentuk menjadi aplikasi dengan bantuan Android Studio, Unity 3D, EasyAR. Tahap keempat yaitu melakukan pengujian terhadap aplikasi yang telah dibuat dan tahap kelima melakukan analisa terhadap aplikasi yang telah dibuat.

\subsection{Analisis Kebutuhan}

Aplikasi HOPE merupakan aplikasi interaktif sebagai media pembelajaran tentang perangkat telekomunikasi menggunakan augmented reality adalah aplikasi yang dibuat untuk mahasiswa dan dosen teknik telekomunikasi, merupakan penggabungan antara media cetak dan teknologi komputer yang nantinya digunakan sebagai aplikasi pada smartphone khususnya android. pada aplikasi HOPE membutuhkan kamera pada smartphone sebagai media input untuk membaca marker (penanda khusus) pada aplikasi HOPE marker yang digunakan berbentuk $Q R$ Code, dimana dari marker tersebut akan menampilkan objek 3D pada layar smartphone. Aplikasi HOPE ini sendiri hasil akhirnya terdiri dari dua bentuk yaitu dalam bentuk fisik (media cetak berupa print out) yang berisikan marker/QR Code dan Aplikasi augmented reality berbasis android yang dapat didownload pada play store.

Pada perancangan aplikasi, terdiri dari aplikasi pendukung dalam proses pembuatan aplikasi HOPE, yaitu dengan perangkat lunak (software) dan perangkat keras (hardware) yang dibutuhkan dalam pembuatan aplikasi ini.

\begin{tabular}{ll} 
Terangkat Lunak & $\begin{array}{l}\text { Tabel } \\
\text { Kerangkat Lunak (Software) } \\
\text { Kerangan }\end{array}$ \\
\hline Sistem Operasi Windows 7 64bit & $\begin{array}{l}\text { Sistem operasi yang digunakan dalam pembuatan } \\
\text { aplikasi }\end{array}$ \\
\hline Android Studio & Tools pengembang bahasa pemrograman \\
\hline EasyAR & $\begin{array}{l}\text { Library augmented reality yang digunakan untuk } \\
\text { membuat aplikasi }\end{array}$ \\
\hline Android SDK & Tools pengembang program android \\
\hline Unity 3D & Sebagai Workspace \\
\hline SketchUp & Pembuatan objek 3D \\
\hline Photoshop CC 64bit & $\begin{array}{l}\text { Pembuatan material ikon-ikon dan template pada } \\
\text { aplikasi }\end{array}$ \\
\hline
\end{tabular}




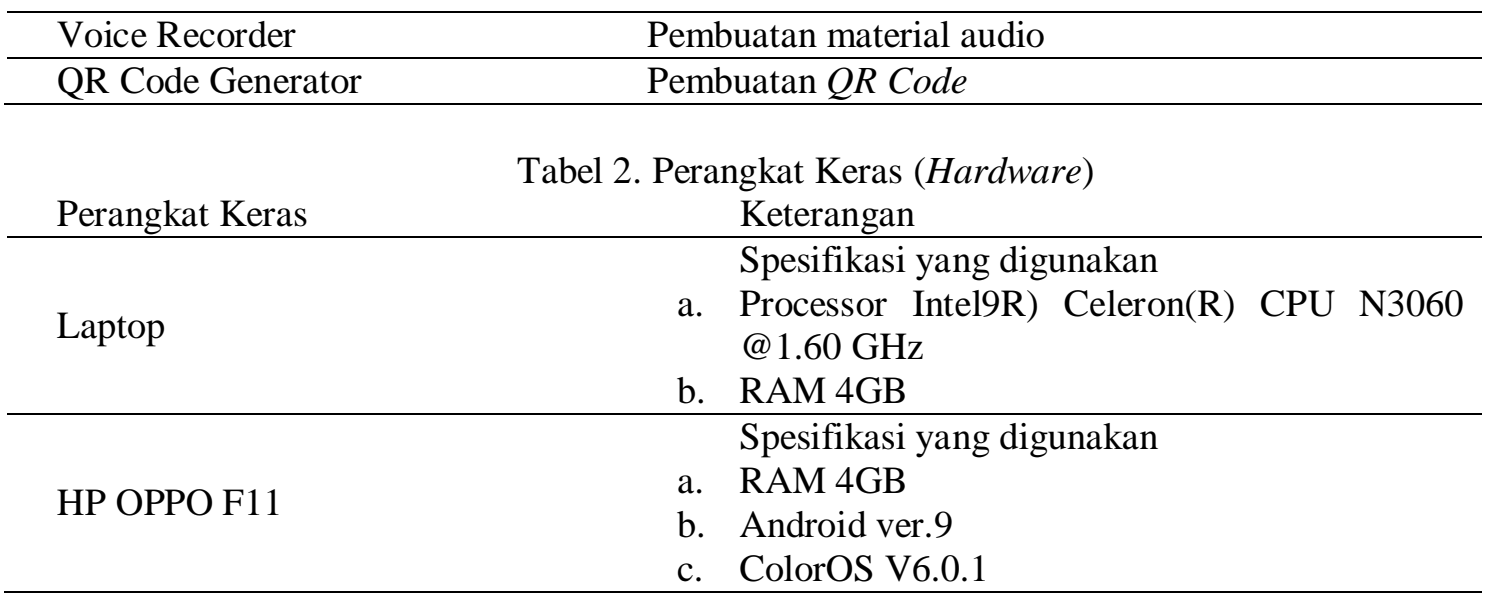

\subsection{Rancangan Aplikasi}

\section{A. Rancangan Algoritma}

Pada rancangan flowchart dimulai dengan sebuah scene splash screen kemudian dilanjutkan dengan proses loading screen kemudian dilanjutkan kedalam menu utama dalam program. Dapat dilihat pada gambar 2.

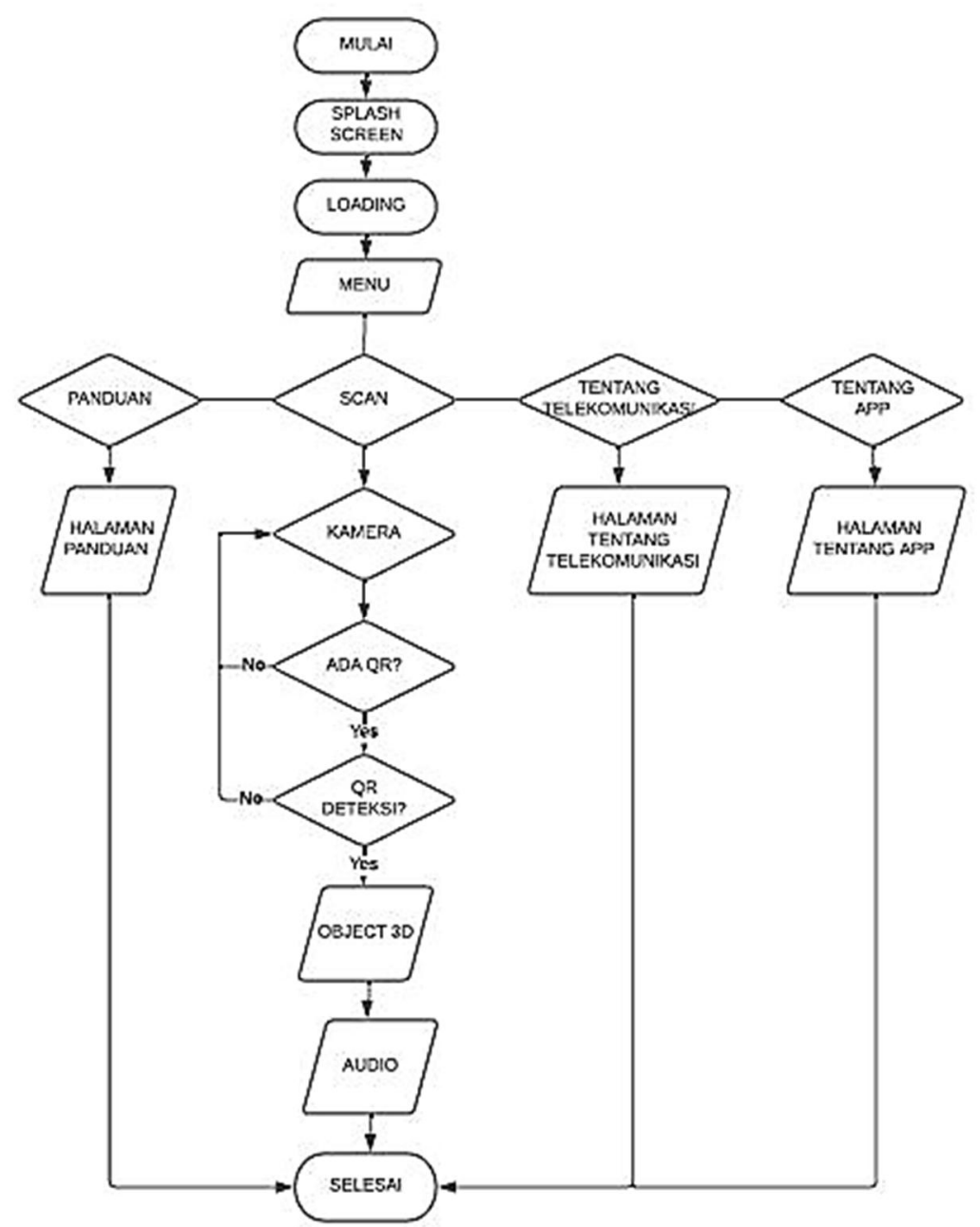

Gambar 2. Flowchart Aplikasi HOPE 


\section{B. Rancangan Struktur Menu}

Perancangan struktur menu menampilkan berbagai menu yang tersedia pada aplikasi HOPE. Semua menu yang ada pada aplikasi digambarkan dalam bentuk hirarki. Tiap-tiap menu terhubung melalui garis yang menyatakan adanya hubungan dari satu menu ke menu yang lainnya. Perancangan struktur menu pada aplikasi HOPE dapat dilihat pada gambar 3.

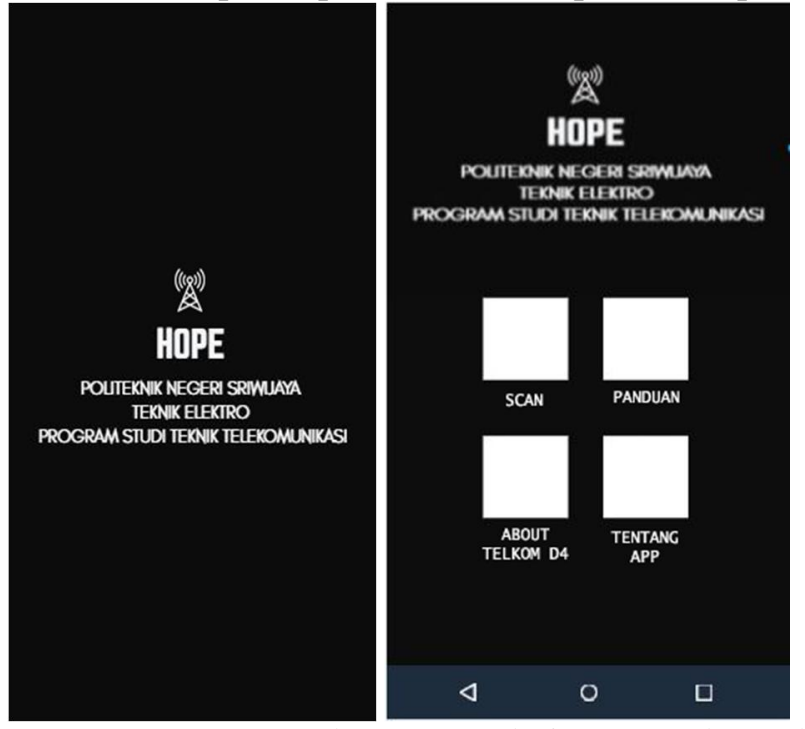

Gambar 3. Rancangan Struktur Menu dari Antarmuka Aplikasi

\section{User Interface}

a. Splash Screen

Pada saat aplikasi dijalankan yang pertama akan tampil adalah halaman splash screen. Rancangan splash ini dapat dilhat pada gambar berikut ini. tampilan halaman splash screen terdiri dari Background dan Textview. Dimana rancangan ini sebagai dasar pengenalan aplikasi pada umumnya dimana memperlihatkan nama aplikasi.

b. Loading Screen

Memiliki fungsi yang sama dengan splash screen namun tampil setelah halaman splash screen.

c. Menu

Tampilan menu akan tampil setelah halaman loading screen. Pilihan menu digunkan sebagai opsi untuk pengguna aplikasi memilih bagian menu yang diinginkan pengguna. Tampilan menu utama terdiri dari empat tombol utama yaitu Scan, Panduan, Tentang Telekomunikasi, dan Tentang App. Rancangan tampilan menu dapat dilihat pada gambar dibawah.

d. Scan

Pada menu pilihan 'Scan' akan mengaktifkan kamera smartphone untuk mendeteksi marker/ QR Code dan menampilkan objek 3D beserta audio penjelasan objek 3D tersebut.

e. Panduan

Tampilan menu ini berisi tentang cara penggunaan aplikasi HOPE, dapat dilihat pada gambar dibawah.

\section{f. Tentang Telekomunikasi}

Menu ini berisikan informasi mengenai sejarah telekomunikasi di Indonesia, dapat dilihat pada gambar dibawah.

\section{g. Tentang App}

Tampilan menu tentang App berisi mengenai pembuat aplikasi. Dapat dilihat pada gambar dibawah. Jika pengguna telah selesai menggunakan menu tampilan tersebut dapat swipe kekiri atau kekanan pada layar. 
Tabel 3. Tampilan User Interface

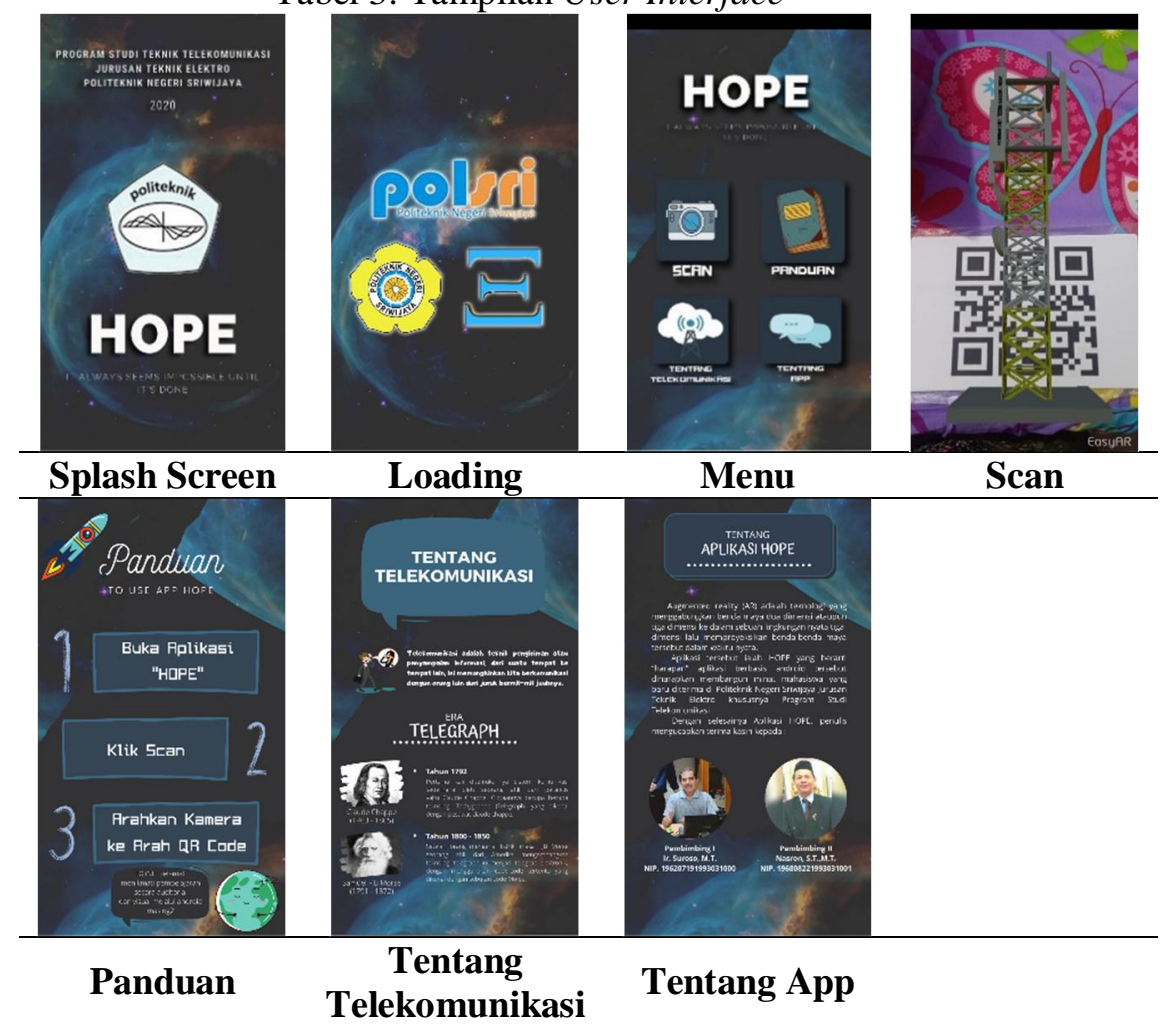

\section{HASIL DAN PEMBAHASAN}

\subsection{Implementasi}

Pada tahap ini object 3D yang dibuat adalah object dari perangkat telekomunikasi yang sering digunakan. Pada menu ini pengguna dapat menggunakan aplikasi selama memiliki aplikasi HOPE dan marker (berupa $Q R$ Code). Gambar marker didapat dengan cara men-scan $Q R$ Code. Ada sembilan objek 3D utama yang dapat di scan menggunakan $Q R$ Code berikut daftarnya.

Tabel 4. Sembilan Object $3 D$

\begin{tabular}{ll} 
No & Nama Objek \\
\hline 1. & Spectrum Analyzer \\
\hline 2. & Radio Detection and Ranging \\
\hline 3. & Base Transceiver Station (BTS) \\
\hline 4. & Satellite \\
\hline 5. & Access Point \\
\hline 6. & Fiber Optic \\
\hline 7. & Internet \\
\hline 8. & Router \\
\hline 9. & Switch PoE
\end{tabular}

\section{A. Merancang Object 3D Menggunakan SketchUp}

Pembuatan object $3 D$ ini memanfaatkan perangkat SketchUp. Dalam menggunakan SketchUp, object $3 D$ yang dibutuhkan adalah object $3 D$ dengan tipe .fbx. proses pembuatan .fbx adalah dengan melakukan eksport kedalam tipe tersebut. 


\section{B. Marker di Unity 3D}

Penggabungan Audio, 3D Object dan menempatkan marker/QR Code dapat dilakukan pada workspace Unity $3 D$. Dimana hasil dapat terlihat pada gambar 4.

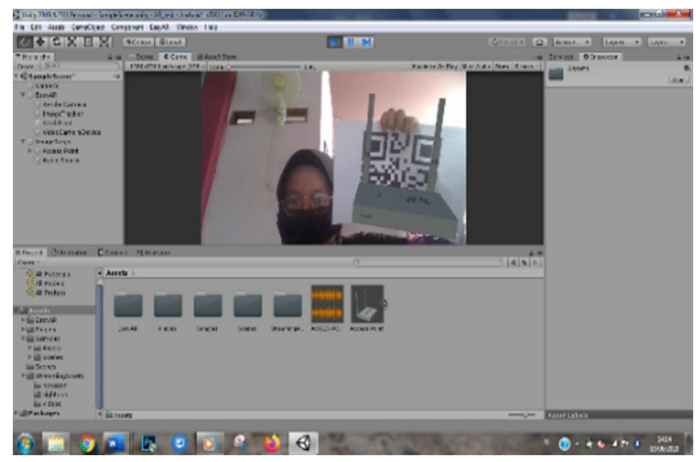

Gambar 4. Tampilan Augmented Reality

\section{Pembuatan Aplikasi}

a. Halaman Splash Screen

Untuk membuat tampilan splash screen membutuhkan empty object pada unity, yang berisikan background, script/kode program untuk lama tampilan splash screen selama 2 detik. Setelah tampilan splash screen selesai tampilan aplikasi akan berpindah ke tampilan loading.

b. Halaman Loading

Untuk membuat tampilan loading membutuhkan empty object pada unity, yang berisikan background, script/kode program untuk lama tampilan loading selama 2 detik. Setelah tampilan loading selesai tampilan aplikasi akan berpindah ke tampilan menu utama.

\section{c. Halaman Menu}

Menu merupakan tampilan yang akan muncul setelah loading. Untuk membuat tampilan menu utama membutuhkan empat objek button. Pengkodean program pada empat objek tersebut terdapat Gui.Button yang merupakan script untuk pembuatan interface tombol di Unity $3 D$.

\section{d. Halaman Panduan}

Tampilan menu ini berisi tentang cara penggunaan aplikasi HOPE, Untuk membuat halaman panduan membutuhkan empty object pada unity, yang berisikan background, script/kode program untuk kembali kehalaman menu dengan cara swipe kekiri/kekanan.

e. Halaman Tentang Telekomunikasi

Halaman ini berisikan informasi mengenai sejarah telekomunikasi di indonesia, Untuk membuat halaman panduan membutuhkan empty object pada unity, yang berisikan background, script/kode program untuk kembali kehalaman menu dengan cara swipe kekiri dan swipe kekanan untuk halaman berikutnya.

\section{f. Halaman Tentang App}

Tampilan menu tentang App berisi mengenai pembuat aplikasi. Dapat dilihat pada gambar dibawah. Jika pengguna telah selesai menggunakan menu tampilan tersebut dapat swipe kekiri/kekanan pada layar.

g. Halaman Scan

Halaman ini merupakan halaman augmented reality perangkat telekomunikasi pada halaman terdiri objek 3D yang telah dibuat untuk menerapkan augmented reality.

h. Compfile Aplikasi ke dalam file APK

Apk adalah sebuah file installer, dalam prosesnya membutuhkan android SDK yang digunakan sebagai compiling program dari seluruh program yang dibuat pada unity $3 D$. 


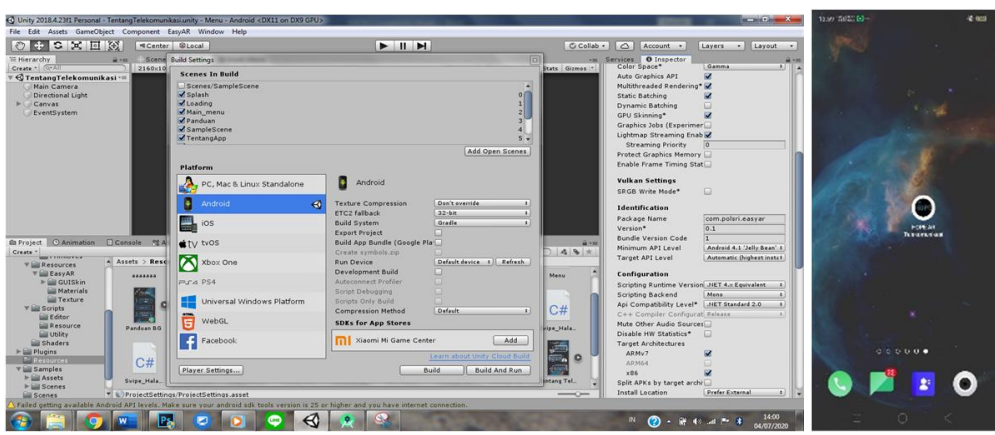

Gambar 5. Compfile Aplikasi kedalam APK

\subsection{Pengujian Aplikasi}

Pengujian ini dibagi menjadi dua yaitu pengujian objek 3D dan pengujian perangkat lunak dimana pada pengujian objek 3D yang dapat diuji berupa jarak, sudut, dan pencahayaan sedangkan pengujian perangkat lunak yang dapat dilakukan dengan metode pengujian Blackbox Testing (pengujian fungsional) dan pengujian non-fungsional (pengujian usability).

\section{Pengujian Marker}

Pengujian ini dilakukan untuk mengetahui efektivitas aplikasi HOPE yang telah dibuat. Sebelum memulai pengujian pada objek 3D pengguna harus memilih salah satu marker berupa $Q R$ Code yang telah disiapkan dalam ukuran $18 \times 18 \mathrm{~cm}$ untuk pengujian pada sudut dan pencahayaan, ukuran $4 \mathrm{x} 4 \mathrm{~cm}$ untuk pengujian pada jarak.

\subsection{Pengujian Jarak}

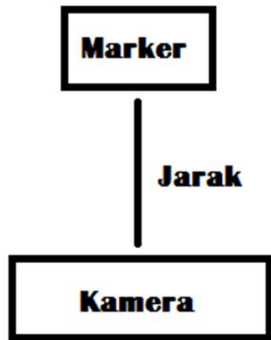

Tabel 5. Pengujian Jarak

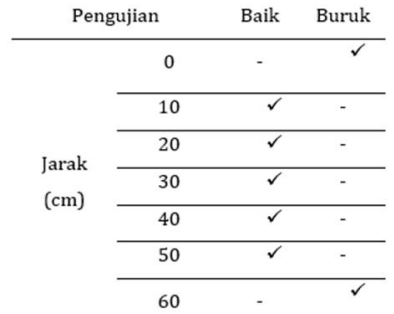

\subsection{Pengujian Sudut}

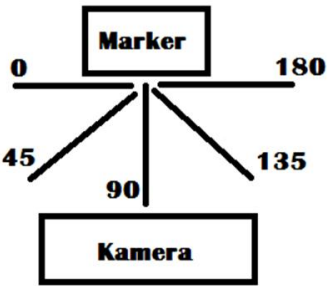

Tabel 6. Pengujian Sudut

Gambar 7. Pengujian Sudut

\begin{tabular}{lccc}
\multicolumn{2}{c}{ Pengujian } & Baik & Buruk \\
\hline & $0^{\circ}$ & - & $\checkmark$ \\
\cline { 2 - 4 } $\begin{array}{c}\text { Sudut } \\
\text { Kemiringan }\end{array}$ & $45^{\circ}$ & $\checkmark$ & - \\
\cline { 2 - 4 } & $90^{\circ}$ & $\checkmark$ & - \\
\cline { 2 - 4 } & $135^{\circ}$ & $\checkmark$ & - \\
\cline { 2 - 4 } & $180^{\circ}$ & - & $\checkmark$
\end{tabular}

\subsection{Pengujian Pencahayaan}

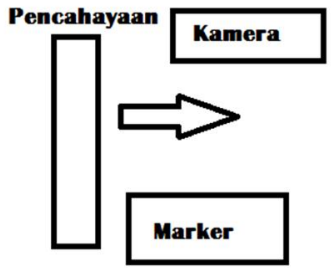

Gambar 8. Pengujian Pencahayaan 
Jatisi

ISSN 2407-4322

Vol. 7, No. 3, Desember 2020, Hal. 559-571 $\quad$ E- ISSN 2503-2933

Tabel 7. Pengujian Pencahayaan

\begin{tabular}{|c|c|c|c|}
\hline \multicolumn{2}{|c|}{ Pengujian } & Baik & Buruk \\
\hline \multirow{7}{*}{ Pencahayaan } & $0 \%$ & - & $\checkmark$ \\
\hline & $10 \%$ & - & $\checkmark$ \\
\hline & $20 \%$ & - & $\checkmark$ \\
\hline & $30 \%$ & - & $\checkmark$ \\
\hline & $40 \%$ & - & $\checkmark$ \\
\hline & $50 \%$ & $\checkmark$ & - \\
\hline & $60 \%$ & $\sqrt{ }$ & - \\
\hline
\end{tabular}

\section{Pengujian Perangkat Lunak}

Pengujian perangkat lunak dapat dilakukan dengan metode pengujian Blackbox Testing (pengujian fungsional) dan pengujian usability (pengujian non-fungsional).

\subsection{Pengujian Blackbox Testing (Fungsional)}

Tabel 8. Blackbox Testing

\begin{tabular}{|c|c|c|c|c|}
\hline \multicolumn{5}{|c|}{ Pengujian Aplikasi HOPE } \\
\hline No & Item Uji & Skenario Uji & Hasil yang diharapkan & $\begin{array}{c}\text { Hasil } \\
\text { Pengujian }\end{array}$ \\
\hline 1. & $\begin{array}{l}\text { Pemasangan } \\
\text { Aplikasi HOPE }\end{array}$ & $\begin{array}{l}\text { Download dan } \\
\text { Install pada } \\
\text { Perangkat }\end{array}$ & $\begin{array}{l}\text { Aplikasi berhasil terinstall pada } \\
\text { perangkat }\end{array}$ & Berhasil \\
\hline 2. & Tampilan Awal & $\begin{array}{l}\text { Memilih } \\
\text { Launcher icon } \\
\text { HOPE }\end{array}$ & $\begin{array}{l}\text { Ketika icon di tekan maka } \\
\text { aplikasi menampilkan Splash } \\
\text { Screen, Loading dan masuk ke } \\
\text { Menu utama }\end{array}$ & Berhasil \\
\hline 3. & Menu Scan & $\begin{array}{l}\text { Memilih menu } \\
\text { scan }\end{array}$ & Menampilkan Menu Scan & Berhasil \\
\hline 4. & $\begin{array}{l}\text { Pemindaian Marker } \\
\text { Access Point }\end{array}$ & $\begin{array}{l}\text { Memindai } Q R \\
\text { Code Access } \\
\text { Point }\end{array}$ & $\begin{array}{l}\text { Menampilkan Object } 3 D \text { dan } \\
\text { Audio }\end{array}$ & Berhasil \\
\hline 5. & $\begin{array}{l}\text { Pemindaian Marker } \\
\text { Base Transceiver } \\
\text { Station }\end{array}$ & $\begin{array}{l}\text { Memindai } Q R \\
\text { Code Base } \\
\text { Transceiver } \\
\text { Station }\end{array}$ & $\begin{array}{l}\text { Menampilkan Object } 3 D \text { dan } \\
\text { Audio }\end{array}$ & Berhasil \\
\hline 6. & $\begin{array}{l}\text { Pemindaian Marker } \\
\text { Spectrum Analyzer }\end{array}$ & $\begin{array}{l}\text { Memindai } Q R \\
\text { Code Spectrum } \\
\text { Analyzer }\end{array}$ & $\begin{array}{l}\text { Menampilkan Object } 3 D \text { dan } \\
\text { Audio }\end{array}$ & Berhasil \\
\hline 7. & $\begin{array}{l}\text { Pemindaian Marker } \\
\text { Internet }\end{array}$ & $\begin{array}{l}\text { Memindai } Q R \\
\text { Code Internet }\end{array}$ & $\begin{array}{l}\text { Menampilkan Object } 3 D \text { dan } \\
\text { Audio }\end{array}$ & Berhasil \\
\hline 8. & $\begin{array}{l}\text { Pemindaian Marker } \\
\text { Switch PoE }\end{array}$ & $\begin{array}{l}\text { Memindai } Q R \\
\text { Code Switch PoE }\end{array}$ & $\begin{array}{l}\text { Menampilkan Object } 3 D \text { dan } \\
\text { Audio }\end{array}$ & Berhasil \\
\hline
\end{tabular}




\begin{tabular}{|c|l|l|l|c|}
\hline 9. & $\begin{array}{l}\text { Pemindaian Marker } \\
\text { Routerboard }\end{array}$ & $\begin{array}{l}\text { Memindai } Q R \\
\text { Code } \\
\text { Routerboard }\end{array}$ & $\begin{array}{l}\text { Menampilkan Object 3D dan } \\
\text { Audio }\end{array}$ & Berhasil \\
\hline 10. & $\begin{array}{l}\text { Pemindaian Marker } \\
\text { Satellite }\end{array}$ & $\begin{array}{l}\text { Memindai } Q R \\
\text { Code Satellite }\end{array}$ & $\begin{array}{l}\text { Menampilkan Object 3D dan } \\
\text { Audio }\end{array}$ & Berhasil \\
\hline 11. & $\begin{array}{l}\text { Pemindaian Marker } \\
\text { Radar }\end{array}$ & $\begin{array}{l}\text { Memindai } Q R \\
\text { Code Radar }\end{array}$ & $\begin{array}{l}\text { Menampilkan Object 3D dan } \\
\text { Audio }\end{array}$ & Berhasil \\
\hline 12. & $\begin{array}{l}\text { Pemindaian Marker } \\
\text { Fiber Optic Cable }\end{array}$ & $\begin{array}{l}\text { Memindai QR } \\
\text { Code Fiber } \\
\text { Optic Cable }\end{array}$ & $\begin{array}{l}\text { Menampilkan Object 3D dan } \\
\text { Audio }\end{array}$ & Berhasil \\
\hline 13. & Menu Panduan & $\begin{array}{l}\text { Memilih Menu } \\
\text { Panduan }\end{array}$ & Menampilkan Menu Panduan & Berhasil \\
\hline 14. & $\begin{array}{l}\text { Menu Teknik } \\
\text { Telekomunikasi }\end{array}$ & $\begin{array}{l}\text { Memilih Menu } \\
\text { Teknik } \\
\text { Telekomunikasi }\end{array}$ & $\begin{array}{l}\text { Menampilkan Menu Teknik } \\
\text { Telekomunikasi }\end{array}$ & Berhasil \\
\hline 15. & Menu Tentang App & $\begin{array}{l}\text { Memilih Menu } \\
\text { Tentang App }\end{array}$ & $\begin{array}{l}\text { Menampilkan Menu Tentang } \\
\text { App }\end{array}$ & Berhasil \\
\hline
\end{tabular}

Pengujian blackbox dilakukan untuk mengetahui aplikasi yang dibuat sudah berjalan dengan baik dan benar dan dapat digunakan oleh orang lain. Pada pengujian black box testing terdapat salah satu metode yang bernama pengujian alpha dimana pengujian alpha adalah metode black box yang fokus pada persyaratan fungsional dari perangkat lunak yang dibangun [6]. pengujian dilakukan oleh 10 pengguna yang dipilih secara acak yang semuanya menggunakan smartphone yang berbeda versi sistem operasi android yaitu versi 7.1.1, versi 8.0, versi 9.0, dan versi 10. berdasarkan hasil pengujian semua fitur di dalam aplikasi dari mulai pertama penginstallan sampai dengan selesai dapat berfungsi dengan baik sesuai dengan kebutuhan.

\subsection{Pengujian Usability}

Pengujian ini bertujuan untuk melihat seberapa kemudahan penggunaan aplikasi oleh mahasiswa Program Studi Teknik Telekomunikasi Politeknik Negeri Sriwijaya. Pengujian dijalankan dengan menggunakan SUS (System Usability Scale) kuisioner yang terdiri dari 10 pertanyaan serta pilihan jawaban dengan nilai $1-5$ yang dimulai dari sangat tidak setuju (STS), tidak setuju (TS), netral (N), setuju (S), sangat setuju (ST) pada masing-masing pertanyaan. SUS (System Usability Scale) dapat digunakan dalam melakukan pengujian teknologi yang independen baik pada perangkat keras, perangkat lunak, website dan bahkan perangkat seluler [7].

Kuisioner yang dibagikan secara online menggunakan google form kepada 30 responden yang terdiri dari mahasiswa aktif Program Studi Teknik Telekomunikasi. Jumlah responden yang digunakan pada pengujian fungsional dan pengujian usability diambil berdasarkan data dari Nielsen yang menyatakan jumlah tersebut sudah lebih dari batas minimal untuk melakukan pengujian secara efektif dan efisien [8] hasil dari pengujian usability dapat dilihat pada tabel 8 .

Selanjutnya adalah menentukan nilai rata-rata dari penilaian responden. Dimana dari 30 responden didapat jumlah nilai sebesar 2534 dan dibagi 30 maka didapat nilai rata-rata sebesar 84,46 hasil responden dapat dilihat pada tabel 8 . Setelah mendapatkan hasil akhir penilaian responden maka selanjutnya adalah menentukan grade hasil penilaian. Untuk menentukan grade hasil penilaian ada 2 (dua) cara yang dapat digunakan [9]. Penentuan pertama dilihat dari sisi tingkat penerimaan pengguna, grade skala dan adjektif rating yang terdiri dari tingkat penerimaan pengguna terdapat tiga 
kategori yaitu not acceptable, marginal dan acceptable.Sedangakan dari sisi tingkat grade skala terdapat enam skala yaitu A, B, C, D, E dan F.dan dari adjektif rating terdiri dari worst imaginable, poor, ok, good, excellent dan best imaginable Penentuan yang kedua dilihat dari sisi percentile range (SUS skor)yang memiliki grade penilaian yang terdiri dari A, B, C, D dan F.

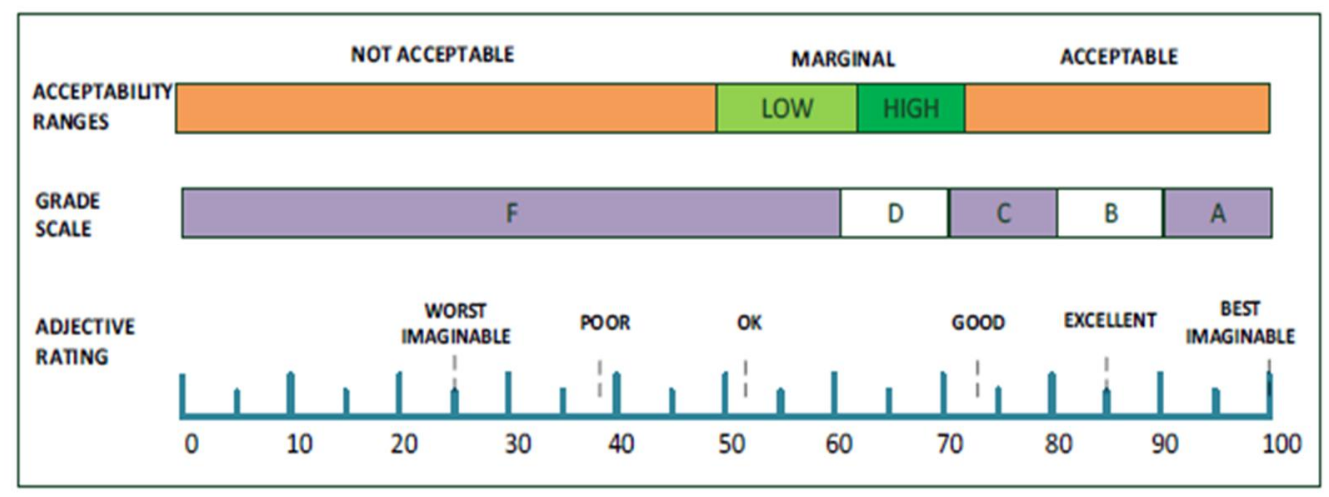

Gambar 9. Penentuan Hasil Penilaian (Bangor, Kortum, \& Miller, 2009)

Untuk melihat sejauhmana perspective pengguna terhadap aplikasi HOPE maka dilakukan perbandingan hasil penilaian rata-rata responden sebesar 84,46. Dari hasil penilaian yang diberikan responden maka hasil penilaian terhadap aplikasi HOPE yaitu tingkat penerimaan pengguna masuk dalam kategori acceptable, dengan grade scale masuk dalam kategori $\mathrm{B}$, dan adjektif rating masuk dalam kategori excellent.

Dalam menentukan SUS skor percentile rank memiliki ketentuan yaitu Grade A dengan skor diatas 80,3, Grade B dengan skor 74 hingga 80,3, Grade C dengan skor 68 hingga 74, Grade D dengan skor 51 hingga 68 dan Grade F dengan skor dibawah 51. Sedangkan berdasarkan ketentuan penentuan hasil penilaian SUS skor maka hasil penilaian responden terhadap aplikasi HOPE sebesar 84,46 berada pada grade A. Sehingga aplikasi HOPE dapat meningkatkan nilai peringkat Indonesia pada aspek kemampuan menerima pembelajaran siswa. Dari hasil penilaian yang diberikan responden maka hasil penilaian terhadap aplikasi HOPE pada skala NPS aplikasi HOPE termasuk kedalam promoters [10]. 
Tabel 9. Hasil Penilaian Responden

\begin{tabular}{ccc}
\hline Responden & Hasil Penilaian & Skor \\
\hline 1 & $38 \times 2.5$ & 95 \\
2 & $36 \times 2.5$ & 90 \\
3 & $33 \times 2.5$ & 83 \\
4 & $31 \times 2.5$ & 78 \\
5 & $30 \times 2.5$ & 75 \\
6 & $34 \times 2.5$ & 85 \\
7 & $34 \times 2.5$ & 85 \\
8 & $32 \times 2.5$ & 80 \\
9 & $31 \times 2.5$ & 78 \\
10 & $32 \times 2.5$ & 80 \\
11 & $33 \times 2.5$ & 83 \\
12 & $35 \times 2.5$ & 88 \\
13 & $39 \times 2.5$ & 98 \\
14 & $32 \times 2.5$ & 80 \\
15 & $30 \times 2.5$ & 75 \\
16 & $37 \times 2.5$ & 93 \\
17 & $32 \times 2.5$ & 80 \\
18 & $35 \times 2.5$ & 88 \\
19 & $34 \times 2.5$ & 85 \\
20 & $32 \times 2.5$ & 80 \\
21 & $32 \times 2.5$ & 80 \\
22 & $33 \times 2.5$ & 83 \\
23 & $35 \times 2.5$ & 88 \\
24 & $39 \times 2.5$ & 98 \\
25 & $32 \times 2.5$ & 80 \\
26 & $30 \times 2.5$ & 75 \\
27 & $37 \times 2.5$ & 93 \\
28 & $32 \times 2.5$ & 80 \\
29 & $35 \times 2.5$ & 88 \\
30 & $36 \times 2.5$ & 90 \\
\hline Rata-rata skor tiap responden & $2534 / 30=84.46$ \\
\hline & &
\end{tabular}

\subsection{Analisa}

Berdasarkan hasil pengujian kita dapat mengetahui bahwa implementasi augmented reality pada aplikasi HOPE cukup mengundang ketertarikan mahasiswa pada augmented reality. Augmented reality menjadi salah satu alternative media yang sangat baik untuk aplikasi. Dengan augmented reality aplikasi akan terasa lebih interaktif dan lebih hidup.

\section{KESIMPULAN}

Dengan adanya sistem aplikasi HOPE untuk media pembelajaran interaktif dapat mempermudah dosen dalam memperkenalkan perangkat telekomunikasi serta mempermudah mahasiswa mempelajari perangkat telekomunikasi. Hasil pengujian marker didapatkan pada hasil pengujian Jarak dalam proses tracking yang baik: $4-50 \mathrm{~cm}$, buruk: kurang dari $4 \mathrm{~cm}$ dan lebih dari $50 \mathrm{~cm}$. Pada pengujian sudut pandang dalam proses tracking yang baik: $45^{\circ}-135^{\circ}$, buruk: kurang dari $45^{\circ}$ dan lebih dari $135^{\circ}$. Pada pengujian cahaya sangat dibutuhkan dalam proses tracking. Penerangan diatas 50\% termasuk baik dan dibawah 50\% termasuk buruk. Dari hasil blackbox testing minimal spesifikasi android pada aplikasi HOPE yaitu versi 7.1.1, versi 8.0, versi 9.0, dan versi 10. Dari hasil evaluasi penilaian yang dilakukan terhadap aplikasi HOPE mendapatkan skor 84,46 yang berarti aplikasi HOPE dinyatakan acceptable termasuk dalam grade A dan B dengan rating excellent, Sehingga aplikasi HOPE dapat meningkatkan nilai peringkat Indonesia pada aspek kemampuan menerima pembelajaran siswa. 


\section{SARAN}

Adapun metode Marker based tracker yang diaplikasikan pada aplikasi ini dapat dikembangkan menjadi metode Markerless. Kedepannya object 3D pada aplikasi HOPE dapat dikembangkan dengan menambahkan berbagai object 3D lainnya. Memperbaiki tampilan dan menambah fitur pada aplikasi sehingga dapat lebih menarik dan menambah fungsional pada aplikasi. Mengembangkan platform yang dapat didukung oleh perangkat lunak mengingat saat ini hanya mendukung pada platform android.

\section{DAFTAR PUSTAKA}

[1] Indah Pratiwi. 2019, "Efek Program PISA Terhadap Kurikulum di Indonesia”. Pusat Penelitian Kebijakan Pendidikan dan Kebudayaan Badan Penelitian dan Pengembangan Kementerian Pendidikan dan Kebudayaan, Jakarta

[2] Siti Dina Safrianti. 2017, "Pengaruh Gaya Belajar Visual, Auditorial, dan Kinestetik Terhadap Hasil Belajar Siswa Kelas X IPS Program Unggulan di MAN”. Universitas Islam Negeri Maulana Malik Ibrahim. Malang

[3] I, Mustaqim. 2016, "Pemanfaatan Augmented Reality Sebagai Media Pembelajaran", Fakultas Teknik, Universitas Negeri Yogyakarta

[4] Bagus S, Prihandoko. 2019, "Implementasi Metode Marker Based Tracking pada Aplikasi Bangun Ruang Berbasis Android”. Teknik Informatika, Fakultas Pascasarjana Teknik Informatika, Universitas AMIKOM Yogyakarta.

[5] N. Asnawi. 2018, "Pengukuran Usability Aplikasi Google Classroom Sebagai ELearning Menggunakan USE Questionnaire”, Jurusan Sistem Informasi, Fakultas Teknik, UNIPMA Universitas PGRI Madiun.

[6] Dias Aziz Pramudita. 2015, "Pengembangan Aplikasi ARTOPENG Sebagai Media Pengenalan Topeng Adat di Museum Sonubudoyo Dengan Teknologi Augmented Reality Berbasis Dekstop”, Program Studi Teknik Informatika, Universitas Negeri Yogyakarta.

[7] U. Ependi, P. Febriyanti, Hutrianto. 2017, "System Usability Scale Antarmuka Palembang Guide Sebagai Media Pendukung Asian Games XVIII”, Program Studi Teknik Informatika, Fakultas Ilmu Komputer, Universitas Bina Darma Palembang.

[8] NIELSEN J. 2017, "Usability 101: Iintroduction to Usability". Tersedia di:http://www.nngroup.com/articles/usability-101-introductionto-usability (Diakses, 03 Agustus 2020)

[9] Rasmila, 2018, "Evaluasi Website Dengan Menggunakan Sistem Usability Scale (SUS) pada Perguruan Tinggi Swasta di Palembang”. Teknik Informatika, Fakultas Ilmu Komputer, Universitas Bina Darma, Palembang.

[10] Sauro, J. 2018, “Measuring Usability With The System Usability Scale (SUS), Measuring Usability". Tersedia pada: http://www.measuringu.com/sus.php (Diakses: 21 Agustus 2020). 